\title{
NATUREZA E SOCIEDADE NOS ALDEAMENTOS INDÍGENAS DO IMPÉRIO: DIÁLOGOS DA ORDEM MENOR DOS FRADES CAPUCHINHOS COM A HISTÓRIA NATURAL'
}

\author{
Marta Amoroso \\ Departamento de Antropologia-FFLCH/USP
}

\begin{abstract}
Resumo
Focaliza-se a montagem dos aldeamentos indígenas administrados pelos frades capuchinhos italianos na segunda metade do século XIX na região dos rios Doce e Mucuri, em Minas Gerais. O foco da análise recai sobre as teorias de natureza e sociedade que orientaram tanto a política de assentamento dos índios como a montagem das colônias de imigrantes implantadas na região. Interessa-nos especialmente acompanhar em que termos, naquele momento particular e falando diretamente do local, formularam-se as noções de natureza e sociedade mobilizadas no projeto de construção e manutenção dos aldeamentos indígenas do Império. Busca-se apresentar o aldeamento indígena de Itambacuri como um caso exemplar da disputa entre programas diferenciados de cultivo da paisagem (T. Ingold, 2000) um tipo de controvérsia que caracterizou, de modo geral, o programa “Catequese e civilização” do governo do Império, voltado para as populações indígenas. O acontecimento da criação do aldeamento indígena e os agenciamentos dele decorrentes, envolvendo os próprios grupos indígenas, imigrantes europeus e migrantes nordestinos, oferecem oportunidade para se considerar, a partir do relato dos missionários e da historiografia da Ordem Menor, quais as possibilidades de diálogo entre ciência e religião no século XIX.

\section{Palavras-chave}

historiografia da Ordem Menor dos Frades Capuchinhos • aldeamentos indígenas do Império Botocudo • Mata Atlântica • naturalistas.
\end{abstract}

\footnotetext{
${ }^{1}$ Apresentado no II Colóquio Internacional “Antigos e modernos: Diálogos sobre a (escrita da) história”, Seminário de Pesquisa “Antigos, modernos e selvagens: Diálogos franco-brasileiros de história e antropologia”. Museu Paulista, USP, 8-12 de setembro de 2009, coordenado por F. Murari Pires, C. Sales de Oliveira, F. Peixoto e C. Zeron. Versões do trabalho foram discutidas e publicadas anteriormente. Parte do trabalho foi apresentada na XXXII Reunião da Anpocs (Caxambu, 27-31 de outubro 2008), no grupo de trabalho "Novos modelos comparativos: antropologia simétrica e sociologia pós-social”, coordenado pelos antropólogos Márcio Goldman e Eduardo Vargas. Uma versão modificada da pesquisa foi publicada na Revista Brasileira de Ciências Sociais, vol. 24, número 71, outubro de 2009 (AMOROSO, Marta. Natureza e sociedade. Disputas em torno do cultivo da paisagem em Itambacuri, 2009). Agradeço os comentários dos coordenadores e dos participantes dos dois encontros. Os microfilmes da documentação capuchinha relativa ao aldeamento de Itambacuri utilizados na pesquisa foram digitalizados pelo Setor de Processamento de Imagens e Reprografia do IEB/USP. Esta pesquisa foi parcialmente realizada no âmbito de um estágio de pós-doutorado no Cebrap subsidiado pela Fapesp. As traduções utilizadas são minhas.
} 


\begin{abstract}
"Ultima ad affacciarsi sulla scala dell’umana civiltà fu l’ America, ultima, per economia di sistema, appare in queste carte. Scoperta da un italiano (1492), avuto o nome da un altro, d' Italia n on vide une spedizione, non ebbe una colonia. Colombo ad Americo erano andati in nome di Spagna, e questa vi distese piú ampiamente a sud ed a nord. Pizzaro e Cortes, se non suonano umanitá nella storia, suanano conquiste". ${ }^{2}$
\end{abstract}

(Rocco da Cesinale, O.F.M.Cap. 1873, p. 439)

\title{
Introdução
}

Em entrevista recente, Ailton Krenak (2009), liderança indígena nascida na década de 1950 nas proximidades do posto indígena Guido Marlière, nas margens do rio Doce, em Minas Gerais, refletia sobre o significado da escrita da história para as populações indígenas da sua região e aludia ao interesse das associações indígenas na guarda do acervo dos naturalistas e viajantes que percorreram a região logo após a abertura dos portos pela Coroa portuguesa, onde encontrariam vestígios da cultura material, vocabulários das línguas indígenas e, sobretudo, histórias de guerreiros indígenas na Mata Atlântica. Comentava que, até o final do século XVIII e início do XIX, a ciência moderna e logo depois a missão cristã tiveram oportunidade de percorrer um trecho ainda bastante intacto de Mata Atlântica que acolhia (e acolhe ainda hoje) ${ }^{3}$ populações Jê, região cujo acesso esteve bloqueado pela Coroa portuguesa no ciclo do ouro, o que beneficiara indiretamente a população nativa. $\mathrm{O}$ acesso à região das fronteiras das províncias de Minas Gerais, Espírito Santo e Bahia foi franqueado depois da abertura dos portos (1808), notícia que atingiu a população indígena na forma da declaração de guerra da Coroa portuguesa contra os Botocudo. Em 1816, começaram a convergir para a região as primeiras expedições de naturalistas europeus e pouco depois se registrou a chegada dos missionários capuchinhos.

\footnotetext{
2 “A América foi a última a se assomar à sequência da civilização humana; última por economia de sistema é o que dizem estas cartas. Descoberta por um italiano (1942), tendo recebido de um outro o nome, a Itália não enviou expedição, não teve colônia. Colombo e Américo foram em nome da Espanha, e esta por ali se espalhou livremente mais ao sul e ao norte. Pizzaro e Cortes, se não significam humanidade na história, significam conquistas”.

${ }^{3}$ A população indígena do Estado de Minas Gerais contabilizaria por etnia, segundo A. Krenak (2009), por volta de 8 mil Xacriabá, 1.200 Maxakali, além de 200 Krenak. A estes se somariam grupos de outros estados que marcaram recentemente presença em Minas Gerais, como os Patachó, os Xukuru-Kariri e os Pankararu.
} 
Voltar à documentação dos naturalistas e missionários, ainda em parte inédita, relativa aos Botocudo na Mata Atlântica, faz todo o sentido para as lideranças indígenas hoje. O cenário flagrado pelos naturalistas servirá de inspiração neste momento de mobilizações das populações indígenas em torno do direito de permanecer no que resta da Mata Atlântica dos rios Doce e Mucuri, e, quem sabe, estabelecer aí uma convivência com a floresta e os rios em regime de sustentabilidade que deverá, necessariamente, reverter as práticas convencionais que se estabeleceram na região a partir de meados do século XIX, depois da chegada dos migrantes e imigrantes.

Os coletivos ${ }^{4}$ formados pela fauna, flora e humanidade identificados pela ciência natural do século XIX nas matas dos rios Doce e Mucuri igualmente nos interessam e são objeto de nossa reflexão por razões um tanto distintas. Busca-se, inicialmente, acompanhar o surgimento dos jardins botânicos criados no ambiente de clima ameno e mata virgem exuberante, assim como observar as condições de produção dos tratados científico-político-religiosos, viabilizados pelas expedições e aldeamentos do Império. Tal exercício nos permite inicialmente refletir sobre a ciência natural em ação, sendo o conceito de jardim botânico referido à produção do conhecimento científico no século XIX, mas que também alude às expedições à Mata Atlântica, anteriores à criação dos espaços de reprodução artificial de espécies da flora e da fauna, identificação e classificação nas instituições das grandes cidades. Em um momento em que os museus de história natural se encontravam em fase preliminar de institucionalização no Brasil, ${ }^{5}$ serão aqui consideradas como próprias dos jardins botânicos as técnicas e práticas que viabilizaram as expedições dos naturalistas tendo em vista a montagem de coleções de história natural, assim como os pontos de encontro de cientistas e técnicos em que se estabeleceram consensos. Estes foram espaços de produção da ciência moderna em que se descreveu conjuntamente natureza e sociedade.

Focaliza-se, assim, em um primeiro momento, as condições de produção do conhecimento da história natural praticada no Brasil por cientistas europeus na primeira metade do século XIX. Em destaque, o grupo de naturalistas que frequentou a fazenda da Mandioca, propriedade do cônsul da Rússia no Bra-

\footnotetext{
${ }^{4}$ Conceitoqueutilizamosno sentidoquea eleatribuiu Bruno Latouremseumanifestode 1991, para aludirà necessidade de superação do dualismo natureza/sociedade que marca a reflexão das ciências modernas. ${ }^{5}$ O Museu Nacional do Rio de Janeiro foi inaugurado em 1818. Sobre a criação dos museus de história natural no Brasil, ver LOPES, Margareth M. O Brasil descobre a pesquisa científica. Os museus e as ciências naturais no século XX. São Paulo: Hucitec, 1995.
} 
sil, G. I. Langsdorff. A fazenda da Mandioca será tomada na análise como um laboratório científico de onde emergiram os debates e alguns consensos sobre a natureza e as populações da América, como também sobre as condições de adaptabilidade do colono europeu, dentro de um programa inédito - que em alguns casos obteve resultados inigualáveis - de classificação dos recursos nãohumanos da fauna e da flora da Mata Atlântica.

Destaca-se a seguir o cenário de criação dos aldeamentos indígenas administradas pelos missionários italianos da Ordem Menor dos Capuchinhos, que foram concomitantes à política de implantação das colônias de imigrantes europeus na região no século XIX. Interessa-nos especialmente acompanhar: 1) em que termos; 2) naquele momento particular, e 3) falando diretamente do local, formularam-se as noções de natureza / sociedade que foram mobilizadas no projeto de construção e manutenção dos aldeamentos indígenas do Império.

\section{0 mal estar de Guido Marlière}

Iniciamos a jornada com o relato de próprio punho de Guido Marlière, militar francês naturalizado no Brasil, que atuava em Minas Gerais a serviço do governo do Império logo depois da chegada da corte portuguesa. O relato de Marlière configurou-se como o mais próximo tanto das populações identificadas como os Botocudo na Carta Régia de 1808, como também das viagens científicas que se seguiram à declaração do Brasil como Reino Unido ao de Portugal (1816). Marlière acompanhou de perto as práticas dos missionários capuchinhos que atuaram entre os Coroados e Puri ao norte da Província do Rio de Janeiro. ${ }^{6}$ Da mesma forma, entrevemos nas narrativas do militar francês a chegada das primeiras expedições de naturalistas nos Campos de Goitacases e nelas o cuidado com a exatidão das descrições, exigência da ciência experimental praticada em campo, que fez de Marlière importante fonte de referência para os naturalistas das diferentes nações europeias que frequentaram a Mata Atlântica no período, que recorriam a ele para conferir dados coletados sobre população, fauna e flora locais. ${ }^{7}$

\footnotetext{
${ }^{6}$ Antes da implantação do aldeamento de Itambacuri na década de 1870, a região contou com aldeamentos dirigidos por frades capuchinhos ainda na década de 1840 no norte da Província do Rio de Janeiro, no Espírito Santo, em Minas Gerais e na Bahia (OFMCap. Metódio da Nembro, 1954). ${ }^{7}$ Sobre a contribuição de G. Marlière à obra de A. de Saint-Hilaire, ver MARLIÈRE, Guido. Notícias e documentos. Revista do Archivo Público Mineiro. [1824] 1904, p. 519-522.
} 
Na década de 1820, pouco antes de assumir o posto de diretor geral dos Índios da Capitania de Minas Gerais, Guido Marlière se dava conta da estranha condição de modernidade de seu tempo, quando na região ainda se cultivava a caça aos índios ("como onças", dizia em uma passagem o militar) nos rios Doce e Mucuri, e também no Jequitinhonha, mais ao norte da província, prática justificada pela condição de gentilidade da população nativa:

Os índios tinham um tribunal (a Junta Militar da Conquista e Civilização dos Índios da Província de Minas Gerais) que os protegia, este tribunal morreu; os índios estão ao desamparo, mortos, perseguidos e espoliados alguns de suas terras; os agressores desculpam-se dizendo que eles não são batizados, e isto no século XIX!! (Guido Marlière, [1822] 1904).

Compartilhar com Marlière este estado de estranhamento nos auxilia a situarmo-nos em debates que envolveram naturalistas europeus, militares e missionários católicos ao longo do século XIX, tendo como foco a Mata Atlântica, nela consideradas as populações nativas, como recomendava a história natural de seu tempo. Em 1824, o militar francês fora empossado diretor dos Índios, cargo para o qual levava a experiência anterior de inspetor das divisões militares da província e o conhecimento adquirido pelo intenso convívio com os Botocudo e Puri da região do rio Doce, onde também mantinha uma propriedade rural, a fazenda Guidowald, na qual sempre contou com o trabalho assalariado dos índios Botocudo. Essa espécie de amizade patronal que o aproximava dos Botocudo em Guidowald permitiu a Marlière registrar seu nome nos anais de Minas Gerais como o pacificador dos Puri da serra da Onça. Os Puri eram considerados feiticeiros pelos Botocudo abrigados na fazenda de Marlière e receberam do Império o tratamento dispensado aos inimigos da Coroa, uma forma de negociação bastante usual na colônia e também no Império, na qual o Estado apoiava-se em dissensões nativas com o objetivo de, por meio delas e das decorrentes ações guerreiras aos contrários, alcançar objetivos estratégicos. ${ }^{8}$

Como diretor dos Índios, Marlière buscou fornecer, aos missionários católicos, cabos militares que falassem as línguas indígenas para atuarem na região. Neste sentido, e apenas neste, Marlière dirigia elogios à missão jesuíta do período colonial, reconhecendo que os jesuítas souberam dar valor ao aprendizado sis-

\footnotetext{
${ }^{8}$ Marlière utiliza a expressão “...usar a mão do gato para retirar as castanhas do fogo”, lembrando a passagem do conto de La Fontaine; no caso, os Campos de Goitacases das populações Puri ocupando a posição das castanhas do conto.
} 
temático das línguas indígenas e, por isso, haviam progredido em sua empresa de aldear os índios, diferentemente do clero nacional que o militar considerava segmento totalmente contaminado pela aversão popular ao índio.

No mais, o sistema de manejo das populações indígenas que Marlière propunha diferia diametralmente do sistema jesuíta. Segundo o militar, os jesuítas "tentavam criar sapos na beira da lagoa”, expressão que adotava para criticar um modelo que considerava por demais aberto e que dava chances aos índios de se evadirem da missão católica. O “sistema mineiro” proposto por Guido Marlière consistia em uma aproximação qualificada dos índios, por meio de intérpretes e do total domínio das línguas, identificação e tratamento diferenciado das chefias, manutenção de roças, oferta de ferramentas etc. Como os rios, dizia, a civilização desceria rumo ao litoral, impedindo as populações nativas de alcançarem, em sua fuga, o sertão. Marlière, ao contrário do programa dos jesuítas, queria os índios aproximados e trabalhando nas plantações e na navegação dos rios; praticara com os Botocudo este tipo de relação patronal que mais tarde vai inspirar o indigenismo leigo do Estado republicano, para o qual o militar francês figurou como ícone da "catequese leiga" (M. Amoroso, 2003).

Assim, podemos considerar que o "sistema mineiro", na definição proposta por Marlière, aludia, para além de uma política de contenção dos índios pelo Império, a populações nativas da Mata Atlântica que, a despeito da guerra recente movida contra elas e da militarização crescente da região, mantinha alguma liberdade e certo domínio de sua história junto à paisagem. Marlière testemunhou um tempo de convívio com grupos e guerreiros Jê que circulavam entre as fronteiras provinciais e se refugiavam na Mata Atlântica ainda bastante intocada, sem abrirem mão do usufruto das roças, ferramentas e apoios estratégicos trazidos pelos equipamentos do Império. Em 1824, Marlière recomendava ao governo da Província de Minas Gerais interessado em resultados na contenção dos Botocudo:

...o querer porém abrigá-los a domínio fixo seria uma quimera, que não se verá realizar, nem eu vejo exemplo disto nos Coroados e Coropos que se estão civilizando desde 1767. Cada família vive separada das outras e a nação se reúne em dias festivos na povoação ou capela onde recebem alguma instrução dos ministros do culto e será prudente seguirmos a esta regra pelo futuro para a cristianização dos Botocudos (Guido Marlière, [1824] 1904, p. 506). 
Veremos a seguir que a particularidade das relações entre as populações nativas e a Mata Atlântica descritas por Marlière foi também franqueada à observação da ciência dos viajantes europeus e obteve registro da história natural.

\section{Dos Andes e Amazônia, passando pela fazenda da Mandioca, rumo ao crânio do Botocudo de Minas Gerais}

Decorridos três anos de sua chegada ao Brasil, G. I. Langsdorff comprou uma fazenda na província do Rio de Janeiro. Denominava-se: “Mandioca”; possuía uma casa grande de dois andares, outras casas que eram arrendadas a viajantes, muitas outras dependências, uma plantação de café com 30-40 mil pés, plantações de mandioca, milho e 36 escravos, o que transmitia a impressão de tratar-se de uma típica fazenda brasileira daquela época. (...) O maravilhoso jardim botânico, a biblioteca que nas palavras dos contemporâneos era constituída "de livros escolhidos sobre todos os ramos das ciências", as diversificadas coleções científicas, como também a possibilidade de receber vários conselhos, fizeram de Mandioca, e da casa do cientista no Rio de Janeiro, lugares constantemente frequentados por viajantes estrangeiros. Ali eles podiam encontrar-se com representantes da intelectualidade da capital, artistas locais ou marinheiros russos. Sem dúvida, era um centro cultural do Brasil de então (B. N. Komissárov, 1981, p. 25-26).

Passamos a acompanhar a montagem das expedições científicas e chamamos a atenção para a especificidade do conjunto de nações europeias que se apresentou para compô-las: a França da restauração monárquica e os países da Santa Aliança - Áustria, Rússia e Prússia -, justamente o conjunto de nações que passou a fornecer neste momento os primeiros grupos de colonos imigrantes para o Brasil. ${ }^{9}$ Trataremos os deslocamentos dos naturalistas pela Mata Atlântica enquanto práticas de pesquisa de campo dos jardins botânicos que resultaram em coleta e montagem de coleções tomadas in loco, tanto de informantes nativos como de colonos europeus adaptados e que nos possibilitam acompanhar a ciência em ação na primeira metade do século XIX, sendo este modelo de prática científica o que servirá de inspiração para as descrições da floresta tropical amazônica que se fará no momento seguinte.

\footnotetext{
${ }^{9}$ O período do Reino Unido (1816-1822) foi marcado por expedições de naturalistas ingleses, prussianos e franceses, como nos mostra a historiadora COSTA, Wilma P. Narrativas de viagem no Brasil no século XIX. Formação do Estado e trajetória intelectual. In: RIDENTI, M.; BASTOS, Elide R.; ROLLAND, Denis (orgs.). Intelectuais e Estado. Belo Horizonte: Editora UFMG, 2006.
} 
Observemos o grupo de europeus que frequenta as instalações da fazenda da Mandioca, na serra da Estrela, Província do Rio de Janeiro, nas primeiras décadas do século XIX. Liderados pelo proprietário do empreendimento, o naturalista e cônsul da Rússia no Brasil, conde de Langsdorff, o grupo contava com outros cientistas ilustres como Wilhelm Ludwig Eschwege, o príncipe Maximilian von Wied-Neuwied, J. Baptista Spix, Karl Friedrich von Martius, J. Emanuel Pohl, interessados em produzir estudos sobre a natureza e a população do Brasil, motivados tanto pela leitura da cosmologia de Alexandre von Humboldt (1769-1859) como pela antropologia física do anatomista J. F. Blumenbach (1752-1840).

Humboldt conhecera e descrevera os Andes e a Amazônia espanhola a partir de viagens pela América do Sul e América Central que transcorreram entre 1799 a 1804, mas fora barrado pelas autoridades portuguesas quando manifestou intenções de estender suas pesquisas até a calha do rio Amazonas. Há, assim, um forte sentido de continuidade já notado pelos comentaristas entre o projeto do grupo de cientistas alemães, suíços e austríacos e as teses e programas de trabalho do autor de Kosmos.

Além dos cientistas, encontraremos, já na década de 1820, ocupando as casas anexas da fazenda da Mandioca de Langsdorf, por volta de 100 colonos alemães e suíços de diferentes profissões, introduzidos na mesma época no Brasil pelo cônsul russo, para serem empregados nas suas plantações e na pequena indústria de sabão que mantinha no local.

Deixemos por ora Blumenbach, sua obra, ${ }^{10}$ as pesquisas de craniometria comparada em andamento em seu gabinete em Göttingen e o impacto deste seu trabalho sobre parte dos cientistas que excursionavam pela Mata Atlântica brasileira. Focalizemos os temas que emergiram do jardim botânico em que se constitui a fazenda da Mandioca, onde, em meio à observação meticulosa e sistemática da fauna e da flora, tratava-se de descrever as populações nativas da América, utilizando o método comparativo, que observava as civilizações andinas e amazônicas em contraste com as populações da Mata Atlântica, assim

\footnotetext{
${ }^{10}$ Segundo A. Gerbi (GERBI, Antonello. O Novo Mundo. História de uma polêmica (1750-1900). São Paulo: Companhia das Letras, 1996, p. 250-254), J. F. Blumenbach (1752-1840), anatomista alemão criador da antropologia física ou comparada, foi um dos primeiros a ver o homem como parte da história natural. Era um nome notório na academia alemã quando da publicação de seu doutorado De generis humani varietate nativa (Göttingen, 1775).
} 
como acompanhava a adaptação dos primeiros colonos europeus que começavam a imigrar para o Brasil. ${ }^{11}$

A reflexão sobre a Mata Atlântica e sobre suas populações nativas processava-se neste ambiente compartilhado na fazenda da Mandioca, onde também se deram as trocas de conceitos e métodos de montagem e conservação de coleções. Nela, planejaram-se expedições inicialmente às províncias ao norte do Rio de Janeiro - Minas Gerais, Espírito Santo e Bahia - que se dirigiriam mais tarde ao Mato Grosso e Amazônia. ${ }^{12}$ Tais espaços de produção científica guardavam em comum um ponto de partida - as teses de Humboldt sobre os nativos da América. Humboldt contrastava as populações nativas do continente sul-americano usando como critério o grau de civilização apresentado. Destacando aquelas que considerava compartilharem um grau de civilização complexa, como as do Peru e do México - e que o naturalista tivera oportunidade de visitar e descrever -, opunha-as às populações das terras baixas do continente sul-americano, que englobavam um conjunto heterogêneo formado desde populações falantes da língua Tupi, consideradas em estágio insipiente de civilização, expresso através do domínio da agricultura, passando pelos Tapuios de “fala travada”, populações do sertão do Brasil, subconjunto identificado como caçadores-coletores. As teses da antropologia física de Blumenbach também entretinham os cientistas da fazenda da Mandioca, assim como as certezas da craniologia e tudo o que ela representava enquanto proposta de um método comparativo.

Nos jardins botânicos sonhados e praticados no século XIX na Mata Atlântica brasileira, as esperanças e as angústias dos novos tempos foram também compartilhadas entre cientistas e o grupo eclético de patrícios europeus, formado por colonos recém imigrados para o continente sul-americano assim como por aqueles que, estando ainda na Europa, alimentavam planos de imigrar para o novo continente e buscavam nos relatos de viagens de história natural uma resposta para suas inquietações. ${ }^{13}$

\footnotetext{
${ }^{11}$ Os estudos sobre a adaptação do imigrante europeu interessaram especialmente a Langsdorf (MANIZER, G. G. A expedição do acadêmico G. I. Langsdorff ao Brasil. São Paulo: Brasiliana, 1967), mas também estão presentes na obra de Maximiliano Wied-Neuwied.

${ }^{12}$ Os pedidos de autorização para a montagem de expedições de história natural na Amazônia e Mato Grosso foram sistematicamente negados neste momento pelo governo do Império, em nome da proteção das fronteiras (COSTA, W. P. Narrativas de viagem no Brasil no século XIX, op. cit., 2006). ${ }^{13}$ Vale aqui aludir ao ensaio merecidamente famoso de Flora Süssekind (SÜSSEKIND, Flora. $O$ Brasil não é longe daqui. O narrador. A viagem. São Paulo: Companhia das Letras, 1990) em que a autora extrapola esta imagem dos naturalistas falando sobre o Brasil para a Europa e coloca o
} 
August de Saint-Hilaire tanto frequentou a fazenda da Mandioca quanto imaginou como seria a sua própria fazenda na Mata Atlântica, o seu jardim botânico. Estando o botânico francês às margens do Jequitinhonha, sonhou adquirir uma fazenda e nela se estabelecer, criando um jardim à l'anglais, daqueles que se obtém abrindo trilhas na mata. A fazenda contaria com a mão-de-obra escrava, devidamente bem cuidada, e com os índios, que seriam atraídos para ela mediante a oferta de presentes (apud W. Dean, 1996, p. 158). O sonho de SaintHilaire, que retomamos abaixo, ilustra a construção de um jardim botânico para o estudo da história natural, onde os homens estavam incluídos em um regime republicano formado por negros e índios, segmentos incorporados pelo naturalista-fazendeiro na condição de trabalhadores braçais em regime de escravidão:

Lançando os olhos sobre o Jequitinhonha, os sonhos que acalentara na primeira juventude após a leitura de S. J. de Crèvecoeur (Cartas de um lavrador americano) voltaram a se me apresentar perante a imaginação. Via-me possuidor de algumas léguas de terra às margens do Jequitinhonha. Chego com um criado fiel e alguns escravos. Levanta-se às pressas um abrigo semelhante aos dos Botocudos, para passar a primeira noite. A princípio passo a existência privado de todas as comodidades da vida; o desejo, porém, de delas gozar, em breve me anima ao trabalho. Parte dos escravos é empregada em cortar árvores nos lugares em que se deverá plantar milho e algodão para o ano seguinte; outros em construir uma cabana. (...) Introduzo leis em minha pequena república; meus negros são bem alimentados, bem vestidos, pequenas recompensas estimulam-nos ao trabalho; bons tratos, provas de interesse tornam-lhes a existência mais suportável, e fazem-nos amar o seu amo. Todos são casados, e acabam por considerar como sua pátria, a dos filhos, e a casa do senhor como a própria. Não me esqueço também dos índios. Começo por atraí-los aos arredores de minha habitação por pequenos presentes. Ficarão certos de receberem presentes todas as vezes que prestarem o menor serviço. Habilito-os pouco a pouco ao trabalho; compreendem em breve, a vantagem de cultivar a terra; fixam-se perto de minha habitação, tornam-se vizinhos prestimosos, e, completo-lhes a civilização tornando-os cristãos. Esses Botocudos, não há muito antropófagos, vêm à minha capela orar por seus inimigos, e sua filha conhece, enfim, o pudor (A. de Saint-Hilaire, 1975, p. 263).

Mas foi o príncipe Maximiliano Wied-Neuwied quem talvez melhor configurou o lugar do cientista natural no novo mundo e vislumbrou as possibilidades que tal cenário anunciava. Na passagem que aludiremos, o príncipe permite-se

leitor brasileiro na condição daquele que busca, nestes registros da história natural, uma definição do que afinal seria o Brasil. 
abandonar a um devaneio às margens do lago do Taípe, entre Minas Gerais e Bahia, última parada do naturalista antes de sua expedição retornar à Alemanha. Acompanhava-o na ocasião um fazendeiro holandês - o sr. Weyl - que recém adquirira uma propriedade na região (por sinal, um aldeamento recém abandonado dos Camacã):

O espetáculo dessa natureza grande, majestosa e selvagem, compensará o sr. Weyl da corajosa resolução de deixar a sua pátria para vir viver unicamente com a sua família nessas remotas paragens. Em qualquer parte do mundo o homem culto encontrará entretenimento e ocupação; mas entre todas as classes, é ao naturalista que cabe a maior vantagem sobre os outros; que campo imenso de observações, que fonte inesgotável de prazer espiritual não lhe proporcionaria essa morada solitária nas nascentes do Taípe! (Wied-Neuwied, 1989, p. 345).

Temos aqui o naturalista europeu, sua capacidade inigualável de observação e gozo dos prazeres da natureza, e, em um segundo plano, o empresário europeu que adquirira fazendas no Brasil e saberia por certo, e a seu modo, usufruir a natureza. Quais lugares ocupariam os Camacã, Machacali, Nacnenuc, Krenak, Pojicha, Puri, Coroado, Botocudo, habitantes da Mata Atlântica e contemporâneos dos naturalistas? Deixemos a resposta por ora em suspenso e adentremos um pouco mais no jardim botânico da fazenda da Mandioca, para conhecer seu proprietário.

G. I. Langsdorff (1774-1852) ${ }^{14}$ formou-se em medicina na Alemanha no final do século XVIII, na Universidade de Göttingen, onde conheceu J. Blumenbach, que foi seu orientador, assim como o filólogo e arqueólogo C. Reine. Em 1800, morando em Lisboa, Langsdorff publicou em alemão e português seus trabalhos na área de medicina, iniciando estudos de botânica, ictiologia e entomologia, que possibilitaram a ele a montagem de uma rede de cientistas europeus - entre eles August de Saint-Hilaire -, alimentada por farta correspondência. Em 1803, tornou-se membro correspondente da Academia de Ciências da Rússia e tomou conhecimento da montagem de uma expedição científica russa que daria a volta ao mundo, para a qual se apresentou, conseguindo o posto de ictiologista e mineralogista.

\footnotetext{
${ }^{14}$ Sobre outras expedições científicas de G. I. Langsdorff, ver: KOMISSÁROV, B. N. O acadêmico G. I. Lagsdorff e sua expedição ao Brasil em 1821-1829. In: BERTELS, D. E.; KOMISSÁROV, B. N; CHUR, L. A. (org.). A expedição científica de G. I. Langsdorff ao Brasil 1821-1829, 1981.
} 
Em 1804, encontramos Langsdorff na costa brasileira, escrevendo sobre a ilha de Santa Catarina. Seguem-se viagens de estudo aos Estados Unidos, Alasca, Sibéria, Japão. Entre 1808 e 1812, Langsdorff permaneceu na Rússia onde empreendeu uma vertiginosa carreira que galgou ocupando inicialmente o humilde posto de ajudante em botânica da Academia de Ciências de Petersburgo, para a seguir alcançar renome nos círculos europeus depois da publicação em Frankfurt do resultado de suas pesquisas botânicas realizadas em Kamtchatka e por fim se estabelecer como cônsul da Rússia no Rio de Janeiro. Assim, ao mesmo tempo em que a corte portuguesa declarava a abertura dos portos do Brasil e, do ponto de vista das ciências da época, o continente sul-americano se abria enfim à pesquisa, Langsdorff fez-se cientista natural, viajante renomado e membro do corpo diplomático residente no Brasil. Como cônsul, foi encarregado de estudar o mercado brasileiro, já que a costa atlântica brasileira era local de parada obrigatória da frota russa a caminho das possessões do czar na América do Norte.

Em 1813, chegou ao Rio de Janeiro e em três anos estaria estabelecido em sua propriedade, a fazenda da Mandioca, na serra da Estrela. Interessado em um novo campo de estudos que se descortinava no Brasil, Langsdorff manteve a Academia de Ciências de São Petersburgo informada dos programas de trabalho de história natural que se processavam aqui, sendo que parte significativa das expedições - a de W. L. Eschwege, a de Maximiliano von Wied-Neuwied, a de I. Franz Werner, a expedição austro-húngara composta por J. B. Spix, K. F. Martius, J. E. Pohl, J. Natterer, e outros -, passou por suas propriedades. Conviveu e trabalhou com Saint-Hilaire assim como conheceu Guido Marlière em Minas Gerais.

Langsdorff viajou em férias para Minas Gerais em 1816, quando delineava os planos para uma grande expedição pelo Brasil que não deixaria a Rússia fora da corrida científica que aqui se estabelecera. Obteve os recursos para a expedição em uma viagem que, passando por Paris para atualizar contatos, seguia com destino à Rússia, onde pretendeu, e obteve com sucesso, angariar recursos. O cônsul retornou ao Brasil em 1822, trazendo um novo quadro de cientistas e pintores: o botânico francês E. P. Ménetriès e o pintor bávaro J. M. Rugendas, além do grupo de imigrantes suíços e alemães que embarcaram com eles no navio Doris, depois de terem aceitado o convite para trabalhar nas propriedades do cônsul. No Brasil se somarão à expedição outros cientistas: Ludwig Riedel, ex-jardineiro em Lion, Nester Gabrílovich Rubtsov, suboficial da marinha mercante russa e Georg W. Freyreiss, cujas habilidades de grande caçador e naturalista serão frequentemente destacadas. Este último, que conhe- 
cera Langsdorff em 1809, chegaria ao Brasil em 1814 e participaria do primeiro núcleo de naturalistas e desenhistas que frequentava a fazenda da Mandioca. As opções de Georg W. Freyreiss ilustram assim certo perfil do praticante da história natural neste momento heróico das ciências naturais: teria oportunidade de acompanhar e colaborar como colecionador nas diversas expedições de naturalistas, assim como de fornecer suas próprias coleções para museus da Alemanha, especialmente depois que decidiu radicar-se definitivamente na Colônia Leopoldina, no sul da Bahia, onde passaria o resto de sua vida entre colonos alemães, até sua morte em 1825.

Blumenbach e Humboldt são referências fundamentais para outro membro da fazenda da Mandioca, Maximiliano de Wied-Neuwied - príncipe da casa renana, que cultivou a ideia de uma expedição para o Brasil por influência de Humboldt, personagem que conhecera em Paris em 1814, quando este, recém-chegado da América do Sul, divulgava seu trabalho na cidade das luzes. Maximiliano alistara-se no exército prussiano que lutou naquele ano em Paris contra Napoleão. Em sua formação acadêmica, Maximiliano frequentara, assim como Langsdorff, a Universidade de Göttingen, onde estudou craniometria com Johann Friedrich Blumenbach e com ele compartilhou a tese da origem comum do homem americano. Chegou ao Brasil em 1815 e retornou em 1817. No Rio de Janeiro, incorporou em sua expedição a dupla de expedicionários que jamais retornou do Brasil: além de G. Freyreiss, que como dissemos acima passou a morar na Colônia Leopoldina, o zoólogo, botânico e desenhista F. Selow (17891831), autor de inspirados desenhos dos Botocudo colhidos em campo e que morreu afogado em uma das expedições coordenadas por Langsdorff. ${ }^{15}$

A Viagem ao Brasil, de Maximiliano, foi publicada e obteve grande sucesso na Europa ainda na década de 1820 (Cf. Rostworowski da Costa, 2008). No Brasil, a recepção da obra do príncipe foi tardia, ${ }^{16}$ ainda que bastante positiva, pelo menos entre antropólogos alemães ou monarquistas: o antropólogo $\mathrm{H}$. Baldus destacava em Maximiliano a sensibilidade de "compreensão de outros fenômenos culturais, que mesmo em nossos dias é alcançada por poucos.” (H. Baldus, 1954, p. 766), enquanto que Câmara Cascudo atribuía ao príncipe a mais

\footnotetext{
${ }^{15}$ F. Selow, por sua vez, conhecia Maximiliano de Paris, como também conhecera aí A. de SaintHilaire. Este desembarcaria no Brasil um ano mais tarde, em 1816, permanecendo até 1822.

${ }^{16}$ Para um contraste significativo, ver em COSTA, W. P. Narrativas de viagem no Brasil no século XIX, op. cit.. 2006, a recepção e o impacto da obra de A. de Saint-Hilaire no Brasil ainda no século XIX.
} 
completa documentação sobre os Botocudo da época, a partir de observação inteligente e qualificada (C. Cascudo, 1977).

Mas o trunfo de Maximiliano sem dúvida consistiu em ter apresentado ao gabinete de Blumenbach o crânio de um jovem Botocudo recém enterrado nas proximidades do quartel de Salto, no rio Belmonte, Minas Gerais. A peça anatômica, como nos descreve o príncipe Maximiliano, fora obtida pessoalmente por ele: munido de picaretas e de certa dose de coragem, enfrentando a opinião pública local formada pelos parentes do rapaz e por militares do destacamento, conseguiu por fim extrair da cova o célebre crânio, tratando logo de conservá-lo para que se tornasse o elemento central de sua coleção (Wied-Neuwied, 1989, p. 262). O crânio seria posteriormente ofertado pelo príncipe ao gabinete de Blumenbach, possibilitando uma oportunidade inédita para a ciência em geral e para o gabinete de seu professor em particular.

A esperança de obter um crânio de botocudo foi um outro motivo que me fez passar aí mais um dia. (...). A uma curta distância das casas, dentro da mata, no meio de uma vegetação bela e florida, havia sido enterrado um jovem botocudo de vinte a trinta anos de idade, um dos mais turbulentos guerreiros de sua tribo. Armados de picaretas dirigimo-nos à sepultura e retiramos o importante crânio. (...) Embora tomasse o maior cuidado em guardar segredo sobre a minha intenção de abrir a sepultura, a notícia em pouco se espalhou pelo quartel, causando forte sensação entre aquela gente ignara. Impelidos pela curiosidade, malgrado um secreto terror, vários se acercaram da porta do meu quarto e quiseram ver a cabeça, que eu, entretanto, escondi imediatamente na mala e tratei de mandar o mais cedo possível para a vila de Belmonte. Se bem que os botocudos como verifiquei, se sentissem menos chocados com o desenterramento que os soldados do quartel, não é menos verdade que muitos deles se recusaram a assisti-lo (Wied-Neuwied, 1989, p. 262-263).

Maximiliano, como é sabido, apresentou às cortes europeias e à ciência de sua época outro jovem botocudo, Quack, este ainda vivo, que seguiu com ele para a Europa. O crânio humano, a coleção de cultura material, da fauna e da flora, assim como a presença do jovem Quack, renderam uma série de considerações que se estabilizaram no ambiente da antropologia física europeia desenvolvida por Blumenbach: a antropologia física iria aproximar o homem americano do tipo malaio, a última das cinco categorias introduzidas pelo antropólogo na sua classificação comparativa das raças humanas. Considerado "o Buffon alemão", Blumenbach adotava a tese da monogenia corrente na biologia do século XIX e situava sua proposta de uma tipologia das raças humanas enquanto um processo de degeneração a partir de um tipo principal (J. C. Greene 1959, p. 222-224). 
Câmara Cascudo atribui ainda a Maximiliano a superação da oposição consensual desde o período colonial e ainda em vigor no Império, entre tupis amigáveis e colaboradores, e tapuias intratáveis, guerreiros inconciliáveis e antropófagos, equívoco que teria orientado os programas de povoamento e colonização do Brasil. Maximiliano, depois de ter convivido com os Botocudo nos destacamentos militares de Minas Gerais e também em suas aldeias, aproximava-os dos Tupi descritos pelos cronistas coloniais. Tal aproximação, entretanto, visava de fato reduzir os Tupi ao baixo rendimento que os Tapuia representavam enquanto objeto da história natural e da ciência da época: "Nos caracteres morais os povos indígenas do Brasil assemelham-se tanto quanto na constituição física. Domina as suas faculdades intelectuais a sensualidade mais grosseira", afirmava Maximiliano, para ressaltar em seguida que tal característica não impedia a eles a capacidade de julgamentos sensatos e agudez de espírito. Seriam ainda capazes de imitar os brancos quando colocados em situação de convivência, mas não seriam, entretanto, guiados por nenhum princípio moral, sendo como eram, sem freios sociais, o que os deixava assim levar-se pelos sentidos e instintos, "tais como a onça nas matas.” A preguiça seria, além de tudo, traço característico que aproximava os Tupi dos Botocudo.

Uma segunda extensão comparativa delineada por Wied-Neuwied, ainda sob a influência de Humboldt, aproximava as populações "do Norte e do Sul", isto é, as populações andinas das terras altas e as populações das terras baixas sul-americanas; as civilizações andinas descritas por Humboldt e os povos indígenas visitados e estudados por Wied-Neuwied em Minas Gerais. Diante de tais balizas comparativas ampliadas, reafirmava que os indígenas de todo continente americano pertenciam à mesma raça. A macrocomparação que a história natural propunha no século XIX para todo o continente sul-americano possibilitava, entretanto, equacionar as populações da Mata Atlântica - botocudos ou não - em relação à civilização andina, restando ao primeiro conjunto a confirmação de que se tratava, senão pela condição da raça, reconhecida como única, mas sim pela brutalidade das suas expressões culturais e morais, de uma humanidade muito próxima dos animais (Wied-Neuwied, 1989).

O que levava o príncipe a tecer tais conclusões, ele que há pouco nos agraciara com páginas tão inspiradas sobre a exuberância do domínio da Mata Atlântica apresentada a ele pelos Botocudo, seus grandes parceiros nas caçadas e na coleta de espécies da flora e da fauna, aqueles que efetivamente viabilizaram a montagem das inúmeras coleções que o príncipe levou para a Europa? Por certo não 
seriam os determinantes da raça: Wied-Neuwied atestara o embranquecimento gradativo de Quack depois de alguns invernos europeus (Wied-Neuwied, 1989, p. 323). Maximiliano cobrava de seus brutos e amigáveis Botocudo a capacidade política de se organizar enquanto lideranças e, assim, controlar - como os andinos descritos por Humboldt - vastos domínios, neles impondo uma cultura a qual qualquer europeu só poderia admirar. No Brasil, terra sem monumentos ou vestígios de hieróglifos, e consequentemente sem uma cultura vigorosa, dizia ele, não se constatavam instituições políticas como os cacicados andinos:

... aos chefes dos tapuias não podemos dar o nome de caciques. Este termo tem sentido muito mais elevado, e não se enquadra com os chefes dos indígenas do Brasil, que não são objeto de nenhuma veneração particular, e em nada se distinguem do restante da tribo; para lhes conferir na horda um voto decisivo, nenhum atributo de superioridade os assinala, tais como a maior prudência, a experiência ou a valentia. Caciques devemos chamar os senhores todo-poderosos dos povos mais adiantados do Novo Mundo, como os mexicanos, os peruanos, e outros, cuja autoridade e cujo poderio, não de raro ilimitado, constituíram forte obstáculo aos conquistadores espanhóis (M. Wied-Neuwied, 1989, p. 325).

E concluía o naturalista:

Quanto estão longe deles [dos caciques andinos] os brutos habitantes das matas virgens do Brasil! Reina aqui a mesma lei que entre os animais, e a maior força dos braços é a única superioridade reconhecida.

Talvez devêssemos sorrir como recomenda I. Stengers (2002) ao final da conclusão a que chega o príncipe na Viagem, na qual os Botocudo são condenados mais uma vez, agora pela ciência, por não portarem instituições que os levariam a reagir a altura à conquista colonial e mais recentemente à guerra que a Coroa portuguesa recém desembarcada no Rio de Janeiro movera contra eles. Motivado pela notícia da publicação do trabalho de Von Eschwege, na qual o mineralogista aludia a uma espécie de monarquia que se delineava entre os Botocudo, em que um rei negro fora entronado e governava os índios nas matas dos rios Doce e Jequitinhonha, Maximiliano descarta esta e outras conjecturas do colega naturalista, demonstrando o quão distante estava a possibilidade de expressão política dos Botocudo: 
Os [índios] do Brasil, portadores de um boné de soldado português, perderam já a sua originalidade, e só pouco interesse despertam (M. Wied-Neuwied, 1989, p. 325).

Os Botocudo rumaram na década seguinte em direção aos aldeamentos indígenas do Império que, na Província de Minas Gerais, tiveram por patrono Teófilo Otoni. Tratava-se agora de uma convivência efetiva com os imigrantes europeus que desembarcavam em Filadélfia, Minas Gerais, atraídos pela propaganda do Império do Brasil e pela empresa de colonização do vale do Mucuri, patrocinada pela família Otoni (Regina Horta Duarte, 2002). O enunciado relacionado aos índios e à Mata Atlântica sofreu então uma sensível alteração, e vemos a mata virgem se converter no temor dos missionários italianos e imigrantes europeus, novos habitantes da região, por representar a selva "a fortaleza dos selvagens". "Mata”, por sua vez, tornava-se uma imagem gradativamente eclipsada pela figura do "solo salubre e ubérrimo" que, nas palavras de T. Otoni e na dos missionários capuchinhos, fora abandonado ao domínio das onças e dos selvagens. Acompanhemos o apagamento da mata que se dá na segunda metade do século XIX, concomitantemente à chegada do imigrante europeu.

\section{Da Colônia Leopoldina a Itambacuri}

O programa de colônias de imigração da Companhia do Mucuri, ${ }^{17}$ conduzido pela família Otoni, dispôs, em um primeiro movimento, colonos e proletários urbanos europeus que convergiram para a região no final da década de 1840 contra os Botocudo. Alegava-se que, na propaganda brasileira a favor da imigração veiculada na Europa, os colonos obtinham garantias de usufruto exclusivo das matas ubérrimas, direito adquirido por contrato firmado com a companhia de colonização. Em um segundo movimento, entretanto, veremos a Companhia do Mucuri aproximar os Botocudo dos proletários urbanos, ${ }^{18}$ à medida que colonos

\footnotetext{
${ }^{17}$ Sobre a colonização do Mucuri e as questões colocadas para as populações indígenas, ver: R. H. Duarte, 2002; I. M. Mattos, 2004 e W. S. Freitas, 2009.

${ }^{18}$ Em relação aos colonos, Teófilo Otoni distinguia dois grupos de imigrantes europeus e ministrava a cada um tratamento diferenciado. Segundo ele, para as colônias de imigrantes almejava-se a vinda de "colonos que pagassem suas passagens e viessem comprar terras à Companhia" (OTONI, T. Notícias sobre os selvagens do Mucuri. Organizado por Regina Horta Duarte. Belo Horizonte: Editora da UFMG, 2002, p. 98), classe de imigrantes que identificava como "lavradores”. Ocorre que a propaganda da Cia. do Vale do Mucuri por vezes atraía certa classe de cidadãos "onerosos e suspeitos”, que T. Otoni classificava como sendo de origem urbana, o "proletariado prussiano", o qual responsabilizava pelos distúrbios frequentes nas colônias.
} 
se organizavam politicamente contra as condições impostas pelos empresários da imigração, e passavam, do ponto de vista das autoridades locais, a ocupar posições similares à dos índios selvagens do Mucuri, tornando-se, como estes, público alvo de policiamento intensivo e de acusações de crime por parte do programa de colonização dos Otoni e do governo do Império.

Contra os "proletários prussianos" e os selvagens Botocudo, a Companhia do Mucuri mantinha, com auxílio das verbas públicas, um destacamento de pedestres e entre os quais alguns cabos falantes da língua dos selvagens - marca deixada por Guido Marlière? -, e considerava serem estes línguas extremamente úteis em função do número de índios que habitava as matas da província em meados do século XIX. O destacamento militar, além de “conter em respeito os selvagens” (T. Otoni, 2002), garantia a presença assídua dos colonos estrangeiros, proletários ou não, nas fazendas, e também dos nacionais, considerados pela Companhia do Mucuri como dados à vadiação e à embriaguez.

Desde o ano de 1846, T. Otoni fixara-se no Mucuri para implantar seu "sistema de generosidade, moderação e brandura” que consistia, basicamente, na substituição de práticas de controle armado e de sequestro das crianças indígenas pela franca distribuição de brindes, ferramentas e o auxílio na montagem dos aldeamentos indígenas financiados pelos governos da província e do Império. Otoni chamava de "bandeira" o novo empreendimento que mantinha direcionado para os índios, num apego às velhas instituições, e pretendia convencer os selvagens "que portugueses e índios do Mucuri (...), todos estávamos efetivamente mansos.” (T. Otoni, 2002, p. 51). Escrita por encomenda do Instituto Histórico e Geográfico Brasileiro (IHGB), sua Notícia sobre os selvagens do Mucuri retomava a desgastada oposição Tupi e Tapuia para reter a imagem dos Tupiniquins de costumes brandos e colaboradores, ${ }^{19}$ dos quais, arriscava ele, possivelmente descenderiam os Machacali.

\footnotetext{
${ }^{19}$ Sobre os Tupiniquim do período colonial, discorria Teófilo Otoni: “... os quais francamente aceitando a civilização portuguesa, e aliando-se em casamentos com os europeus, fizeram prosperar nos primeiros anos a capitania de Porto Seguro a ponto de começarem logo os colonos a exportar para a metrópole grandes porções de açúcar. Mas poucos anos duraram a prosperidade da capitania, vítima que foi dos ataques dos aimorés, pataxós, abatirás” (...) “a tal ponto que em 1587 só restava um engenho em toda a capitania, continuando por dois séculos em completa decadência (...).” (OTONI, Teófilo. Notícias sobre os selvagens do Mucuri, op. cit., 2002, p. 43). Sobre a reedição no Império do debate colonial sobre a oposição Tupis e Tapuias, ver MONTEIRO, John. Tupis, tapuias e historiadores. Estudos de história indígena e do indigenismo. Tese de livre-docência. Campinas: Unicamp, 2001.
} 
A tese de T. Otoni era a de que as serras, os montes, os vales e os rios do Alto Mucuri e do Jequitinhonha não estiveram sempre sob o domínio ("estúpido”) dos Botocudo, seus atuais moradores. Ali já existira no passado quem soubera fazer valer os recursos da terra, não os atuais Botocudo, que subsistiam da caça, e por isso manifestavam grande necessidade de deslocamento, sendo assim "mais infelizes, e menos industriosos que os tártaros, não têm para conduzir em suas excursões nem tendas nem rebanhos." (Teófilo Otoni, 2002, p. 88). E completava:

Os matos circunvizinhos demonstram a modo irrecusável uma cultura que cessou há muitos anos, e que aquele solo já foi teatro de uma civilização mais adiantada. A simples inspeção do terreno, sobretudo das taperas, prova que seus atuais ocupantes são intrusos. (...) E não é só a vegetação do país que fala esta linguagem. A terra, para denunciar a barbaridade dos botocudos, guardou em depósito instrumentos de indústria, importados de fora por seus antigos senhores, e os artefatos locais, que não deixam dúvida alguma sobre esta civilização mais adiantada que ali existiu (T. Otoni, 2002, p. 88).

Teófilo Otoni recordava que ele mesmo, auxiliado por alguns colonos europeus de Filadélfia, podia apresentar telhas coloniais e outros artefatos encontrados que comprovavam a movimentação dos Tupiniquim da costa para as serras. Os terrenos que hoje atraíam migrantes e imigrantes pela fertilidade e salubridade do solo e que restavam "sob o domínio das onças e dos selvagens", continham, segundo ele, provas suficientes de que a presença atual dos Botocudo em Mucuri, Doce e Jequitinhonha era recente. Finalizava sua explanação constatando que ocorrera uma evidente decadência no tipo de ocupação nativa da região, com o que se somava à opinião dos primeiros naturalistas. Mas diferentemente destes, que tendiam a uniformizar a caracterização das populações do continente sul-americano, T. Otoni demonstrava tratar-se de tipos diferentes de agrupamentos e, consequentemente, possibilidades distintas de colonização. Assim, o interesse pelos Botocudo vivos declinava na exata proporção que se enaltecia o pretérito encontro colonial com os Tupi da costa, esta sim uma experiência de convívio profícua, que se mostrava agora inviável com as populações nativas contemporâneas, habitantes da Mata Atlântica. 


\section{Das selvas ao solo ubérrimo}

Nas selvas dos vales do Mucuri e do rio Doce (F. J. Palazzolo, [1954] 1973) ${ }^{20}$ é o título da memória da missão que elege a selva como protagonista principal, ainda que pretenda em sua singeleza capuchinha tratar da transformação ou conversão dos índios Nacnenucks, Potes, Giporoks, Pojichá do aldeamento de Itambacuri, Minas Gerais. A selva, neste enunciado, é o desafio que a missão deveria vencer ao implantar um regime de "desertinação e povoamento", ${ }^{21}$ seguido do cultivo extensivo do "solo ubérrimo".

O missionário de Itambacuri, frei Serafim de Gorísia, trazia sólida formação acadêmica anterior ao ingresso na Ordem Menor, o que por certo o distinguia do conjunto de missionários que atuaram no Brasil no período da missão do padroado. Chegou a Minas Gerais na década de 1870, acompanhado de outro missionário, frei Ângelo de Sassoferrato, tendo por tarefa aldear os Botocudo do Mucuri, considerados “o maior obstáculo para a colonização europeia” pretendida pela Companhia do Mucuri. O fato de a Propaganda Fide do Vaticano encaminhar para Minas Gerais missionários que dominavam a língua alemã revelava, diferentemente do que a narrativa capuchinha buscava afirmar quando associava missionários exclusivamente à catequese dos índios, que, ao órgão encarregado das missões de catequese, o apostolado voltado para os índios necessariamente envolvia o acompanhamento da adaptabilidade dos colonos europeus imigrados e a difícil questão da convivência forçada entre índios, migrantes e imigrantes nos aldeamentos indígenas do Império.

\footnotetext{
${ }^{20}$ Gênero que guarda em comum com outras memórias de missionários do século XIX forma, tom e abrangência, a memória de Itambacuri se apresenta como peça política de defesa da missão católica no contexto regional, como de resto se volta para o público católico estrangeiro que usualmente teve acesso às memórias esparsas dos missionários capuchinhos antes do público brasileiro. O volume examinado, copilado na década de 1950 pelo superior dos capuchinhos, frei Jacinto de Palazzolo, foi veiculado na coleção Brasiliana, da Companhia Editora Nacional, conquistando grande público, sendo talvez a obra capuchinha mais conhecida do leitor brasileiro. Alceu de Amoroso Lima cuida da apresentação do volume e nela revela a probabilidade de uma ascendência nobre de frei Serafim de Gorísia, que pertenceria à nobreza austríaca e privara na juventude da amizade do imperador Francisco José (PALAZZOLO, frei Jacinto de. Nas selvas dos vales do Mucuri e do rio Doce. Belo Horizonte: Itatiaia; São Paulo: Edusp, 1973, p. 22). Além da memória, dispomos sobre Itambacuri de uma das mais prolixas correspondências do período, assinada por seus missionários, frei Serafim de Gorísia e frei Ângelo de Sassoferrato (Arquivo da Custódia do Rio de Janeiro dos Frades Capuchinhos, ACRJ).

${ }^{21}$ ACRJ, Correspondência de frei Serafim de Gorísia, Itambacuri, 12/08/1882.
} 
Nos registros da Ordem Menor, Itambacuri foi considerado um dos mais bem sucedidos aldeamentos do período, onde se buscou promover de forma institucionalizada a mestiçagem, tema caro à antropologia, que pode se debruçar sobre tal experimento de convívio de agrupamentos variados, promovido pelo Estado em meados do século XIX, e, a partir dele, acompanhar algumas das questões que daí emergiram. A primeira delas diz respeito exatamente ao caráter oficial da mistura das raças que se buscou processar nesta região de Minas Gerais, ${ }^{22}$ cabendo aqui indagar como isso se deu e de que forma conferiu-se o resultado da política de mestiçagem. Notemos, quanto a este ponto, que, para cumprir seu lema, a missão, amparada pelo Estado, não pretendeu fazer colonos europeus mais adaptados à Mata Atlântica pela via da mistura com os nativos; a mistura almejada, que tinha por objetivo converter índios em trabalhadores cristãos, dirigia-se estritamente a índios e imigrantes pobres de Minas Gerais e do Nordeste.

Chama à atenção a particularidade deste projeto de mestiçagem, na qual a mistura "oficiosa" praticada em todo continente (Otavio Velho, 2005) aqui se revestia de caráter oficial, de política pública do Estado e das práticas missionárias. A Propaganda Fide e o Vaticano, proclamando a necessidade da romanização do catolicismo, imprimiam à missão dos capuchinhos italianos do século XIX um caráter de modernidade: os missionários falavam em nome de um novo tempo que se implantava no sertão com a chegada das estradas de ferro; das vacinas acionadas contra as epidemias e outros avanços da medicina; das estradas e das novas redes de comércio e comunicação. E, principalmente, dos imigrantes europeus. A modernidade se traduzia nos aldeamentos indígenas na conversão, isto é, na transformação dos índios em cristãos trabalhadores. A purificação, isto é, o índio convertido em trabalhador católico, era aqui obtida por meio da mistura. Neste sentido, os mestiços foram considerados, por frei Serafim de Gorísia, a comprovação do sucesso do aldeamento cristão:

E tem sido justamente em virtude da união e aliança entre trabalhadores indígenas com lavradores nacionais, que se tem conseguido aqui a mais acertada e espontânea transforma-

\footnotetext{
${ }^{22}$ Experiências similares não pretenderam cumprir esta recomendação oficial, como no aldeamento de São Pedro de Alcântara, no vale do Tibagi, Paraná, dirigido por frei Timotheo de Castelnovo. Em São Pedro de Alcântara, a missão capuchinha registrará a inviabilidade de se aproximar colonos migrantes e imigrantes dos agrupamentos Kaiowá, Mbyá e Kaingang, assim como de reunir, em um mesmo aldeamento, grupos indígenas distintos (AMOROSO, Marta. Catequese e evasão. Etnografia do aldeamento indígena de São Pedro de Alcântara, Paraná (1855-1895). Tese de doutorado. Departamento de Antropologia da FFLCH-USP, São Paulo, 1998).
} 
ção dos selvagens prejudiciais em laboriosos nacionais mestiços, desaparecendo de modo imperceptível pela mesma metamorfose, ou por morte natural, o alto algarismo de índios puros, terror dos habitantes desta fértil região, povoando-se a extensa e espessa floresta, abrigo outrora de feras bravias (frei Serafim de Gorísia, 1889, cf. Palazzolo, 1973, p. 172).

A mistura se conferia por meio da celebração dos casamentos entre índios e nacionais pobres, promovidos pelo aldeamento, sendo que os missionários, depois de dispensadas as formalidades do casamento civil, e com isso exercendo o pouco do espaço de liberdade que detinham frente ao Estado, passavam eles mesmos a documentar o resultado da experiência da mistura racial promovida nos aldeamentos. Nos censos e registros da missão e do Estado, o índio já não era mais índio, ou não era assim considerado pela missão. Ao mesmo tempo, os missionários eram levados, vez por outra, a reintroduzir os índios em alguns dos censos, de forma a garantir as verbas dos governos e a condição diferenciada dos religiosos, de administradores de aldeamentos indígenas. Talvez porque nunca se soube ao certo, ao longo da segunda metade do século XIX, onde mesmo se encontravam os índios considerados aldeados pelo programa "Catequese e civilização”. Uma questão que mobilizava as autoridades dos governos e para a qual a missão capuchinha dava, invariavelmente, respostas evasivas, foi a da demarcação das terras dos aldeamentos. Os missionários declaravam que era impossível realizar a demarcação, os índios aldeados continuavam espalhados pelos rios. Qualquer tentativa de definição mais detalhada dos limites do território dos aldeamentos mobilizaria a oposição dos colonos abrigados nos aldeamentos indígenas, de um lado, e de outro, a oposição dos missionários, que afirmavam que perderiam catecúmenos indígenas dispostos a 30, 40, 60 léguas da sede da missão, como pudemos ver nos aldeamentos dos vales do Tibagi e Paranapanema, ao sul da Província de São Paulo (M. Amoroso, 1998).

A segunda questão aborda o tema da "construção da felicidade" que o projeto cristão compreendia, como nos coloca B. Latour (2004b), o que em Itambacuri passava pela transformação dos Botocudo em "laboriosos mestiços nacionais", isto é, a construção da pobreza, tema caro à Ordem Menor dos Frades Capuchinhos desde o seu surgimento (Le Goff, 2001). Para avançar um pouco mais nesse ponto somos levados de volta aos coletivos formados pela Mata Atlântica e os seus nativos, agora uma paisagem pensada em termos das cidades de Deus erguidas sobre os terrenos ubérrimos administrados por missionários italianos e demais cristãos laboriosos. Neste novo cenário, a mata se apresentava para a missão dos capuchinhos como o maior desafio a ser vencido, juntamente com os 
Botocudo. O território imenso e a "medonha floresta" são personagens das narrativas do segundo missionário de Itambacuri, frei Ângelo Sassoferrato, que alertava àqueles que consideravam fácil a tarefa de perseguição dos índios salteadores:

... assim só podia arrazoar quem não conhecesse as matas do Brasil, que são de tal ordem, que serviam para os índios de fortalezas seguras e inexpugnáveis.

Frei Ângelo de Sassoferrato, em outra passagem, disposta na estrutura de sua Memória no tempo anterior à chegada da missão, descrevia a Mata Atlântica:

Aos europeus causavam pasmo as árvores seculares do Brasil, de 30, 40 e mais metros de altura e grossura extraordinária. Estávamos rodeados destas extensíssimas florestas virgens, abrigo de onças e tigres ferozes e de selvagens ainda mais temerosos (frei Ângelo Sassoferato, cf. Palazzolo, 1973, p. 40).

Dez anos depois de montado o aldeamento de Itambacuri, em 1883, frei Serafim tratava o equipamento missionário como um estabelecimento "belo e pitoresco”, com centenas de quilômetros de terras próprias para a agricultura, águas potáveis e clima benéfico, onde a mata cedera espaço para a edificação do urbano da missão. Afirmava que o aldeamento fora chamado a preencher o imenso vácuo de florestas sem habitante "afora os selvagens", que mediava "a cidade de Teófilo Otoni ao rio Doce, e de São Mateus ao Pessanha, e quiçá não seja esta região a precursora de um esplêndido futuro de extraordinária prosperidade (...)”. Um ano antes expunha qual seria o lugar dos índios no projeto:

... nenhuma colonização se sujeitará a ser tão firme e perseverante no trabalho rural desta zona como o indígena uma vez civilizado, que se acomoda logo a usos e costumes da nação e ambiciona a se aliar aos pobres lavradores, levando-lhes vantagem de ser pouco exigente e menos interessado; e afinal os índios, de combinação feita com os nacionais de gênio industrioso, ocupam-se todos os anos em desbravar porções de espessas brechas, prestam só com isso o melhor serviço que se pode exigir deles: o que não se obtém com o terror que perpetua o ódio entre as raças, consegue-se com a catequese, mão caridosa aos infelizes (frei Serafim de Gorísia, ACRJ 20-II-31, 12/07/1882).

As ameaças constantes de ataques de “índios selvagens”, no entanto, permanecem. Frei Serafim de Gorísia referia-se, por exemplo, à "presença de negros fugidos ou mandados...”, vivendo entre os índios Pojichá que, como vimos, é um tropo recorrente nas narrativas dos naturalistas. Esses líderes africanos "que lhes dão conselhos e os governam e ajuntam lá no centro de São Mateus, fazendo-se 
cada vez mais perigosos", ${ }^{23}$ Da mesma forma que mata virgem aludia aos espaços de sociabilidade que escapavam ao controle do Estado e da missão, aldeamentos, na retórica missionária, seguiam identificados a espaços da fraternidade de índios trabalhadores. É o que acompanhamos nas notícias dos conflitos, como aquele que envolveu o Consulado Alemão no Brasil e as autoridades do Império convocadas pelo recurso de um abaixo-assinado dos colonos europeus e nacionais do município de Filadélfia a resolver a questão dos ataques dos Pojichá aos colonos:

Passando assim as coisas, não me admira que os estrangeiros e nacionais laboriosos dessas paragens queiram o extermínio dos Pojichás por lei de necessidade, cuja efetuação seja de todo impossível, por que são numerosos, táticos e desconfiados e podem chamar em socorro outros índios, aos vizinhos e utilizando às costas para refúgio a espessa e desconhecida mata virgem (frei Serafim de Gorísia, ACRJ 20-III-56, 30/06/1885).

Restaria indagar como as práticas dos frades capuchinhos nos aldeamentos do Brasil dialogaram com as regras da Ordem Menor dos Frades Capuchinhos e os dogmas vigentes da Igreja Católica. Encontrei algumas respostas na obra de frei Rocco de Cesinale, historiador da Ordem Menor, que conheceu e acompanhou de perto o trabalho dos missionários de Itambacuri, como dos demais frades italianos que estiveram no Brasil e no Congo nesta época. Notemos que frei Rocco de Cesinale, ao tratar dos índios do Brasil, abordava as relações que existiam entre ciência e religião no século XIX, e chegava mesmo a convocar para o debate o naturalista A. Humboldt, ao destacar o diálogo possível entre a linguística e a religião:

A língua, disse Alexandre Humboldt, como criação intelectual da humanidade, como profundamente inerente a seu desenvolvimento espiritual, é para a nação da qual ela é própria, de uma alta importância, para ajudar a reconhecer a semelhança e a diversidade da raça [Cosmo, I, 334] (frei Rocco de Cesinale, 1837, p. 508).

Esta passagem abria o capítulo "Il Tupi” da sua Storia delle missione del cappuccini, publicada em Paris em 1837. Nas décadas seguintes, frei Rocco de Cesinale tornou-se geral da Ordem Menor dos Frades Capuchinhos da Propaganda Fide no Vaticano no momento em que a missão de Itambacuri foi criada em Minas Gerais. Neste cargo, conheceu os missionários Ângelo de Sassoferato e Serafim de Gorízia em 1872 em Roma, quando estes, vindos de suas provín-

${ }^{23}$ Arquivo da Custódia do Rio de Janeiro, 20-III-51, 15/3/1885. 
cias de origem, Ancona e Gorízia, localizadas no interior da península Itálica, se apresentaram ao comissário geral, pouco antes de embarcarem em Gênova, rumo ao porto do Rio de Janeiro. ${ }^{24}$

O contato direto com os missionários que percorreram a África ${ }^{25}$ e o continente sul-americano, aliado à posição que ocupou na hierarquia da Ordem Menor dos Frades Capuchinhos, deu as bases para uma reflexão que se fazia em franco diálogo com a ciência de sua época, no caso, a cosmologia de A. Humboldt; a linguística de J. H. Klaprot (1783-1835, orientalista e expedicionário alemão), os tratados de Conrad Malte Brun (1775-1826, geógrafo dinamarquês), de A. Balbi (1782-1848, geógrafo veneziano) e Remusat; a botânica de Smith Barton (1766-1815, médico e botânico norte-americano também formado na Universidade de Göttingen), autores citados pelo historiador capuchinho. A Storia delle missione cappuccini, de Rocco de Cesinale (1887), explicitava como a missão cristã do século XIX acompanhou as formulações da história natural e o debate em torno da origem do homem travado por monogenistas e poligenistas. A ciência apresentava-se para os religiosos católicos envolvidos com a missão no Brasil como uma espécie de reflexão auxiliar, que propiciava à religião cristã uma reorientação de suas práticas de construção da felicidade nos espaços de atuação dos capuchinhos na África e no continente sul-americano.

Em um aldeamento indígena no interior do Brasil ou em uma aldeia no Congo, na África, a missão capuchinha do século XIX pensava em termos da origem comum da raça humana, sendo a questão da diversidade um ponto polêmico da reflexão cristã, que se resolvia por meio do estudo das línguas. Assim, refletindo sobre os Tupi da costa do Brasil e também os do interior do continente - os Apiacá e os Mundurucu, populações onde a missão italiana mantinha aldeamentos ${ }^{26}$-, frei Rocco de Cesinale usava a língua tupi como

\footnotetext{
${ }^{24}$ O Arquivo Histórico do Itamaraty, no Rio de Janeiro, guarda os registros da chegada dos missionários capuchinhos italianos contratados pelo governo do Império durante o Segundo Reinado para atuarem nos aldeamentos indígenas nas províncias do Brasil. Ver: Ministério das Relações Exteriores. Ofícios da Cidade do Vaticano (período 1840-1889).

${ }^{25}$ É à Storia..., de R. de Cesinale que Pierre Verger recorre para pensar o lugar da missão católica na construção dos deuses fetiches entre os Yorubá, no Congo do século XIX. (VERGER, Pierre. O deus supremo Ioruba; uma revisão das fontes Odu, Um. Of Ife. Journal of African Studies, 1966). ${ }^{26}$ A missão capuchinha neste momento se implantara também no rio Tapajós e mantinha por lá frei Pelino de Castrovalva, outro missionário italiano e diretor do aldeamento indígena de Bacabal, entre os Mundurucu. (AMOROSO, Marta. Primeira missa. Memória e xamanismo na missão capuchinha de Bacabal. In: MONTERO, Paula (coord.). Deus nas aldeias. Missionários, índios e mediação cultural. São Paulo: Editora Globo, 2005).
} 
documento de que a humanidade encontrada no continente sul-americano pertencia de fato uma só família linguística.

Para tanto, estabelecia uma aproximação entre os métodos da etnografia filológica e da antropologia física, esta dedicada aos estudos sobre as medidas e aspectos dos crânios, demonstrando que ambas operavam por meio de comparações sistemáticas. Por fim, afirmava como as ciências modernas, em seus procedimentos de exercício comparativo e de construções de analogias, como os que se davam nos gabinetes germânicos de antropologia física ou nas bibliotecas dos filólogos, chegavam a conclusões que guardavam imensas semelhanças com o que estava expresso na Bíblia. Assim, o exame da estrutura comum a todas as línguas americanas não deixava dúvida de que estas pertenciam a uma só família. Os missionários, dizia, observaram desde muito cedo que certas línguas indígenas no Brasil, como o tupi, podiam ser consideradas como chave de outros dialetos e sobre estas bases construíram o programa de catequese do continente. Descoberto tal parentesco, tratava-se agora de traçar as linhas de aproximação do tupi com a língua do antigo mundo, e também, nesta vertente de pesquisa, o parentesco entre as línguas seguia confirmado.

Se até aquele momento o Novo Mundo fora pensado em termos das distâncias que guardava do Velho Continente, e desta apreensão resultara o registro de uma multidão de línguas isoladas entre si e igualmente distantes e estranhas às línguas europeias, Rocco de Cecinale defendia que a nova ciência que agora operava a partir da observação dos fatos e da identificação dos sistemas - numa clara alusão ao paradigma científico inaugurado por A. Humboldt (A. Gerbi, 1996, p. 304-305) -, tendia a reduzir a diversidade a poucos sistemas, o que lhe permitia demonstrar que ciência e religião estavam por demais próximas ou, melhor dizendo, que a ciência dos naturalistas avançava em direção a conclusões há muito demonstradas na Bíblia.

Aludindo às condições de implantação do programa missionário no Brasil, que fora possibilitado pela língua geral, e expondo as coleções de catecismos, orações dominicais e gramáticas das línguas indígenas coletadas pelos missionários ao longo dos séculos, Rocco de Cesinale apresentava este tipo de material como prova das inúmeras semelhanças entre as línguas tupi.

A missão capuchinha praticada em Minas Gerais pelos missionários italianos guardava, dessa forma, grande proximidade em sua prática com o exercício de reflexão de um historiador da Ordem: tratava-se de enfrentar em ambos os campos a decomposição apenas aparente do universo tendo em vista sua 
representação recomposta. No caso de Itambacuri, a missão católica pretendeu apresentar a mistura purificadora da qual emergiria a unidade possível, o índio que pela mistura das raças era feito cristão laborioso.

\section{Conclusão}

Focalizamos os diálogos da Ordem Menor dos Frades Capuchinhos com a história natural, restando, para a conclusão, acompanhar como a interlocução da missão do padroado com a ciência refletiu na escrita da história promovida pela Ordem neste momento.

Quanto aos diálogos da Ordem Menor dos Frades Capuchinhos com a ciência, vimos que os capuchinhos aproximavam sua reflexão a respeito do Brasil e dos "povos intertropicais" dos resultados recentes da linguística fonológica e da antropologia física praticada por Blumenbah, servindo ambas as ciências para corroborar a interpretação bíblica da origem comum do homem. Para a prática missionária, tal consenso amparou, em Itambacuri e nos aldeamentos indígenas onde os capuchinhos atuaram no Brasil, um programa de cultivo da paisagem que, orientado para índios e pobres nacionais, visava prioritariamente acolher o imigrante europeu.

$\mathrm{Na}$ escrita da história das missões capuchinhas encontraremos algumas respostas para o sentido político da presença da missão capuchinha italiana no Brasil no II Reinado. Tratei anteriormente (M. Amoroso 2006) o que a Storia delle missione del cappuccini de Rocco de Cesinale representou para a memória da presença dos capuchinhos no Brasil: para sua execução o provincial mobilizou a documentação dos hospícios da Ordem Menor do Brasil o que resultou, ao que parece, em um trágico desfecho - o extravio da documentação referida à missão no Brasil. Acompanhar o lugar que o Brasil ocupa nesta obra de fôlego - que trata literalmente de todos os tempos e lugares da missão capuchinha - se revela um exercício bastante revelador.

O tema “missões capuchinhas no Brasil” ocupa um lugar discreto, entretanto significativo no conjunto da obra: um capítulo final (XXI) no Livro I intitulado Maranhao e o penúltimo capítulo do Livro III, intitulado Brasile. A história do Brasil promovida pela historiografia capuchinha no século XIX destacava as ações evangelizadoras e de capelania militar dos frades da OFMCap., de forma a colocar os frades no epicentro das ações que resultaram no descobrimento da América, na expulsão dos calvinistas, na construção por fim do catolicismo 
no novo continente. Os capuchinhos aparecem também como os mártires da expulsão dos holandeses e do calvinismo de Pernambuco.

O provincial desloca o eixo da história das descobertas ibéricas para dar destaque à reivindicação dos monarcas franceses ${ }^{27}$ pela participação no espólio das conquistas e às sucessivas ações que decorreram de tal insatisfação: a montagem de colônias francesas no Rio de Janeiro, Maranhão e Canadá. Um aspecto interessante da tessitura da história da Ordem Menor dos Frades Capuchinhos é que os índios - il brasiliani - constituem o início da história da nação brasileira, uma operação que possibilitou ao provincial encontrar os missionários capuchinhos da Normandia e suas exuberantes notícias dos índios do Maranhão, antes de falar em Brasil. Tratando da missão capuchinha no Maranhão, a interpretação do provincial capuchinho frisava que a cristandade teve que aguardar a chegada dos frades bretões para ter conhecimento "do tipo de civilização que portavam àqueles gentios” (1887, p. 441): em quase um século de colonização Portugal mantivera o monopólio da notícia da descoberta das suas possessões na América, ficando a cargo dos capuchinhos Claude d'Abbeville, Ive d'Eureux e Francisco da Bourdemare "os primeiros sinais da história brasileira”²8 (1887, p. 444).

O capítulo Brasil, por sua vez, tem início na narrativa histórica de frei Rocco de Cesinali em 1641, ano da chegada em Olinda dos capuchinhos franceses ${ }^{29}$ da província da Bretanha (fundada anos antes, em 1634), da participação da capelania militar capuchinha na expulsão dos holandeses e do início do trabalho de conversão dos selvagens ao catolicismo.

Assim, os frades capuchinhos da Propaganda Fide inscreviam no final do século XIX sua presença na história no Brasil de forma a reivindicar, ainda que tardiamente, sua parte no espólio colonial. Neste momento, a Ordem ocupava lugar de destaque no programa “Catequese e civilização” do governo do Império do Brasil, programa que praticamente garantia o monopólio aos frades italianos.

\footnotetext{
${ }^{27}$ Rocco de Cesinale explicava que, neste momento, meados do século XVII, “...os capuchinhos gozavam plena vida de juventude na França” (CESINALE, frei Rocco de. Storia delle missione del cappuccini. Paris, 1887, p. 441).

28 “A avidez dos primeiros colonos e o temor que se descobrisse que tipo de civilização levavam àqueles gentios, tinha produzido tamanho monopólio de informações, que os relatos de Claude d'Abbeville, Ive d'Eureuxe Francisco da Bourdemare foram os primeiros sinais da históriabrasileira, esomentenos nossos tempos, rigorosos e severos, Silva Lisboa e Constancio" (CESINALE, frei Rocco de, op. cit., p. 444). 29 “A missão francesa e a italiana foram por algum tempo a mesma no Brasil” (CESINALE, frei Rocco de, op. cit., p. 693), esclarecia ele em outra passagem, estabelecendo uma linha de continuidade da presença italiana no Brasil que remontava à chegada do primeiro capuchinho no continente sul-americano.
} 
À Itália - sem jamais ter enviado expedições à América ou obtido possessões coloniais - estava reservado, afinal, um lugar de honra no novo continente, conquistado por missionários e mártires capuchinhos, os mesmos que agora implantavam os aldeamentos indígenas do Império e a um só tempo acolhiam os imigrantes oriundi que abordavam a Mata Atlântica no século XIX.

\section{Referências bibliográficas}

AMOROSO, Marta. Catequese e evasão. Etnografia do aldeamento indígena de São Pedro de Alcântara, Paraná (1855-1895). Tese de doutorado, Departamento de Antropologia da FFLCH/USP, São Paulo, 1998.

AMOROSO, Marta. A longa era da catequese dos índios. V Reunião de Antropologia do Mercosul. Florianópolis (ms), 2003.

AMOROSO, Marta. Primeira missa. Memória e xamanismo na missão capuchinha de Bacabal (rio Tapajós 1872-1882). In: MONTERO, Paula (coord.). Deus nas aldeias. Missionários, índios e mediação cultural. São Paulo: Editora Globo, 2003.

AMOROSO, Marta. Natureza e sociedade. Disputas em torno do cultivo da paisagem em Itambacuri. Revista Brasileira de Ciências Sociais, v. 24, n. 71, p. 55-72, 2009.

BALDUS, Herbert. Bibliografia crítica de etnologia brasileira. São Paulo: Comissão do IV Centenário, 1954.

CÂMARA CASCUDO, Luis da. O príncipe Maximiliano no Brasil (1815-1817). Biografia e notas. Rio de Janeiro: Livraria Kosmos, 1977.

CESINALE, fr. Rocco de. Storia delle missione del cappuccini. Paris, 1887.

COSTA, Wilma P. Narrativas de viagem no Brasil no século XIX. Formação do Estado e trajetória intelectual. In: RIDENTI, M.; BASTOS, Elide R. \& ROLLAND, Denis (orgs.). Intelectuais e Estado. Belo Horizonte: Editora UFMG, 2006.

DEAN, Warren. A ferro e fogo. A história e a devastação da Mata Atlântica brasileira. São Paulo, [1995] 1996.

FREIRHEYSS, G. W. Viagem ao interior do Brasil. Belo Horizonte: Itatiaia; São Paulo: Edusp, 1982.

FREITAS, Wender Silveira. “Mansos como cágados”. A Companhia do Mucury e os índios. Dissertação de mestrado PPGSC/Universidade Federal da Bahia, 2009.

GERBI, Antonello. O Novo Mundo. História de uma polêmica (1750-1900). São Paulo: Companhia das Letras, 1996.

GREENE, John C. The dead of Adam. Evolution and its impact on western though. Iowa: The Iowa State University Press, 1959.

INGOLD, Tim. Humanidade/animalidade. Revista Brasileira de Ciências Sociais, 28 (10), p. 39-54, 1994. 
INGOLD, Tim. The perception of the environment. Essays on livelihood, dwelling and skill. London/ N. York: Routledge, 2000.

INGOLD, Tim. A evolução da sociedade. In: FABIAN, C. (org.). Evolução: sociedade, ciência e universo. Bauru: Edusc, 2003.

KOMISSÁROV, B. N. O acadêmico G. I. Langsdorff e sua expedição ao Brasil em 1821-1829. In: BERTELS, D. E.; KOMISSAROV, B. N. \& CHUR, L. A. (orgs.). A expedição científica de G. I. Langsdorff ao Brasil 1821-1829. Catálogo completo do material existente nos arquivos da União Soviética. Brasília: Sphan/Fundação Pró-Memória/Ministério da Educação e Cultura, 1981.

KRENAC, Ailton. Genocídio e resgate dos “Botocudo”. Entrevista com Ailton Krenac. Revista de Estudos Avançados/USP, vol. 23, n. 65, janeiro/abril de 2009.

LATOUR, Bruno. Jamais fomos modernos. Ensaio de antropologia simétrica. Rio de Janeiro: Editora 34, 1991.

LATOUR, Bruno. Ciência em ação. Como seguir cientistas e engenheiros sociedade afora. São Paulo: Editora Unesp, 2000.

LATOUR, Bruno. Políticas da natureza. Como fazer ciência na democracia. Bauru, SP: Edusc, [1999] 2004.

LATOUR, Bruno. “Não congelarás a imagem”, ou: como não desentender o debate ciência-religião. Mana, 10 (2), 2004.

LOPES, Margareth M. O Brasil descobre a pesquisa cientifica. Os museus e as ciências naturais no século XX. São Paulo: Hucitec, 1995.

LE GOFF, Jacques. São Francisco de Assis. São Paulo: Record, 2001.

MANIZER, G. G. A expedição do acadêmico G. I. Langsdorff ao Brasil. São Paulo: Brasiliana, 1967.

MARLIÈRE, Guido. 1904. Notícias e documentos. Revista do Archivo Público Mineiro, 1904, p. 3-254, v. XI.

MATTOS, Isabel Missagia de. Civilização e revolta. Os Botocudos e a catequese na Província de Minas. Bauru, SP: Edusc, 2004.

METODIO DA NEMBRO, O.F.M.Cap. Storia dell'attività missionária dei Minori Cappuccini nel Brasile (1538-1889). Roma: Institutum Historicum Ord. Fr. Min. Cap., 1958.

METODIO DA NEMBRO, O.F.M.Cap. I capuccinni nel Brasile. Milano: Centro Studi Cappuccini Lombardi, 1957.

METODIO DA NEMBRO, O.F.M.Cap. Le missioni cappuccine nel Brasile durante il primo Impero e la Reggenza (1822-1840). Collectanea Franciscana 27, 1957, p. 385-415.

MONTEIRO, John. Tupis, tapuias e historiadores. Estudos de história indígena e do indigenismo. Tese apresentada para o concurso de Livre-Docência, Campinas: Unicamp, 2001. 
OTONI, Teófilo. Notícias sobre os selvagens do Mucuri. Organização de Regina Horta Duarte. Belo Horizonte: Editora UFMG, 2002.

PALAZZOLO, frei Jacinto de. Nas selvas dos vales do Mucuri e do rio Doce. São Paulo: Brasiliana, [1952] 1973.

ROSTWOROWSKI DA COSTA, Cristina. O príncipe Maximiliano Wied-Neuwied e sua "Viagem ao Brasil". Dissertação de mestrado, História Social, FFLCH/ USP, 2008.

SAINT-HILAIRE, Auguste de. Viagem ao Espírito Santo e rio Doce. Belo Horizonte: Itatiaia; São Paulo: Edusp, 1974.

SAINT-HILAIRE, Auguste de. Viagens pelas províncias do Rio de Janeiro e Minas Gerais. Belo Horizonte: Itatiaia; São Paulo: Edusp, 1975.

STENGERS, Isabelle. Ainvenção das ciências modernas. São Paulo: Editora 34, 2002. STOCKING JR., George W. Victorian anthropology. New York: The Free Press, 1987.

SÜSSEKIND, Flora. O Brasil não é longe daqui. O narrador. A viagem. São Paulo: Companhia das Letras, 1990.

VELHO, Otávio. Comentários sobre um texto de Bruno Latour. Mana 11(1), 2005.

VERGER, Pierre. O deus supremo Ioruba; uma revisão das fontes. Odu, Um. Of Ife. Journal of African Studies, 1996, vol. 2, n. 3.

VIVEIROS DE CASTRO, Eduardo. Imagens da natureza e da sociedade. In: A inconstância da alma selvagem - e outros ensaios de antropologia. São Paulo: Cosac \& Naify, 2002.

WIED-NEUWIED, Maximiliano. Viagem ao Brasil. Belo Horizonte: Itatiaia; São Paulo: Edusp, 1989.

\section{Manuscritos:}

Correspondência dos missionários capuchinhos de Itambacuri, MG. Arquivo da Custódia do Rio de Janeiro dos Frades Capuchinhos.

Ministério das Relações Exteriores. Arquivo Histórico do Itamaraty. Ofícios da Cidade3 do Vaticano (1840-1899).

Nota biográfica: Marta Amoroso é docente do Departamento de Antropologia da Universidade de São Paulo. Trabalha com etnologia da Amazônia e história dos índios. Esta reflexão faz parte das atividades do projeto "Paisagens ameríndias: habilidades, mobilidade e sociabilidade nos rios e cidades da Amazônia - Procad”, da Capes, realizado pela USP/Ufam. 
Título Revista de História

Projeto gráfico da capa e miolo Joceley Vieira de Souza

Diagramação/editoração Joceley Vieira de Souza e Indara R. M ayer

Divulgação Humanitas Publicações

Formato $160 \times 220 \mathrm{~mm}$

Mancha $130 \times 192 \mathrm{~mm}$

Fontes utilizadas Times $\mathrm{New}$ Roman, Futura $\mathrm{Md} \mathrm{Cn} \mathrm{Bt}$

Papel Off-set $75 \mathrm{~g} / \mathrm{m}^{2}$ (miolo); Supremo $250 \mathrm{~g} / \mathrm{m}^{2}$ (capa)

$N^{\circ}$ de páginas 304

Tiragem 500 exemplares 